\title{
DEVELOPMENT OF A GARLIC ROOT AND STEM CUTTING MACHINE M. M. IBRAHIM ${ }^{(1)} \quad$ M. F. ATHAI ${ }^{(2)}$
}

\begin{abstract}
The main purpose of this research is to design a garlic root and stem cutting machine suitable for cutting root and stem part of the garlic. It can help farmer to reduce human effort and degree of discomfort involved during cutting. A garlic cutting machine was designed, fabricated and evaluated for its performance and techno-economic feasibility. Some shearing properties of garlic stem that are pertinent to the mechanical processing were measured and considered in the design of the machine. The developed machine was evaluated at three levels of knife speed $\left(K_{S}\right)\left(8.5,12.1\right.$ and $\left.20.5 \mathrm{~m} \mathrm{~s}^{-1}\right)$ and two levels of garlic bulb moisture content $\left(M_{C}\right)(61.5 \%$ and $70.3 \%$ w.b. $)$. The Evaluation was based on the following parameters: machine capacity $\left(P_{m}\right)$, bulb damage (BD), consumed energy (CE) and cost. The results recommended operating the machine at combinations of $K_{S}=8.5 \rightarrow 20.5 \mathrm{~m} \mathrm{~s}^{-1}$ and $M_{C}$ value of $61.5 \%$ to maximize $P_{m}$ with minimize $B D$. The garlic cutting machine increased the capacity to about 1.5 times and reduced the cutting cost to about $29.2 \%$ comparing with manual method.
\end{abstract}

Keywords: Garlic, root, stem, cutting, design, damage.

\section{INTRODUCTION}

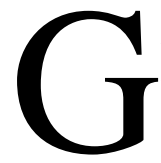
Arlic (Allium sativum L.) has been used as a food, a condiment, and for medicinal purposes for many centuries. Garlic is one of the most widely used traditional culinary herbs in the world. In Egypt, the cultivated area of garlic is about $11875 \mathrm{Ha}$ and production is 280216 tons (FAOSTAT, 2016). Postharvest treatments of garlic may be performed treatments were included in the trial, both separately and in combination: tops cut; roots cut; washed; high-tunnel dried; and open-air dried. Before the garlic is sent to market for retail selling, the roots and stems of garlic are required to be removed. This operation processed by hand labour. Due to scarcity of agricultural labour (in Egypt villages), farmers find it difficult to complete this task in time.

(1) Assoc. Prof., Ag. Eng. Dept., Fac. of Agric., Cairo University.

(2) Water relations and field irrigation Dept., Agric. and Biolog. Research Division, National Research Centre. 
The proposed machine is intended to help the farmers to cut the root and stem in the proposed processing time. The garlic roots cutting were cut while garlic still moist using a pruning or knife shears, where cares was taken not to damage the basal plate. The heights of top cutting were six inches, while garlic was green. Qi et al. (2011) stated that the factor affects the cutting process is the cutting tools. The knife sharpness can significantly affect storage life, whereas dull knives cause bruises and damage to the tissue layers (Gil and Allende 2012, Mishra et al., 2012). The most familiar geometric shapes of fresh-cut vegetables and fruits are: disc, baton, cube, shred and slice. The shapes depend on the types of product and their requirement (Koidis et al. 2012). For some fruits like mango and yellow melon, it is important to determinate the cutting types for their processing (Ngamchuachit et al. 2014; Russo et al. 2012). The value addition through packaging, storage and other post harvest technologies of garlic will be root and stem cutting. So, the objective of the present work is to design, fabricate and evaluate a low-cost garlic root and stem cutting machine.

\section{MATERIALS AND METHODS}

\subsection{Sample preparation}

The garlic bulbs (Egyptian Baladi variety) were randomly collected from different farms. Similar to local practice, the bulbs were dried by spreading in a thin-layer inside a darkroom with open windows near the farms for 15 days. The garlic moisture content was determined by following ASAE, (1999a) standard. The samples were, weighed and the moisture content was calculated in percent wet basis (w.b.).

\subsection{Physical and mechanical properties of garlic}

Some physical and mechanical properties of garlic bulb that are related to the cutting processing were measured and considered by the design of the machine.

\subsubsection{Dimensions, mass and volume of garlic bulb}

Some physical properties of garlic bulb were determined by Ibrahim (2013). The properties that were measured are presented in Table (1).

\subsubsection{Static coefficient of friction}

The friction static coefficient of bulb garlic with different materials, plywood, galvanized metal and rubber was determined by Ibrahim (2013) at moisture 
content of $70.3 \%$ determined, the friction static coefficient of bulb garlic are presented in Table (1).

Table (1): Some physical and mechanical properties of garlic bulb.

\begin{tabular}{|c|c|c|c|c|c|}
\hline \multicolumn{2}{|l|}{ Property } & Min. & Max. & Mean & Stand. Dev. \\
\hline \multicolumn{2}{|l|}{ Length, mm. } & 30.6 & 41.7 & 36.5 & 3.1 \\
\hline \multicolumn{2}{|l|}{ Width, mm. } & 39.9 & 71.9 & 51.4 & 6.8 \\
\hline \multicolumn{2}{|c|}{ Thickness, mm. } & 40.2 & 65.6 & 50.7 & 5.9 \\
\hline \multicolumn{2}{|l|}{ Mass, g. } & 87.6 & 45.3 & 62.5 & 11.6 \\
\hline \multicolumn{2}{|l|}{ Volume, $\mathrm{cm}^{3}$. } & 30.6 & 41.7 & 36.5 & 3.1 \\
\hline \multicolumn{2}{|c|}{ Bulk density, $\mathrm{g} \mathrm{cm}^{-3}$. } & 0.41 & 0.56 & 0.45 & 0.25 \\
\hline \multirow{3}{*}{$\begin{array}{l}\text { Coefficient of } \\
\text { friction. }\end{array}$} & Metal & 0.28 & 0.70 & 0.42 & 0.09 \\
\hline & Wood & 0.30 & 0.68 & 0.30 & 0.08 \\
\hline & Rubber & 0.43 & 0.73 & 0.5 & 0.10 \\
\hline
\end{tabular}

\subsubsection{Shearing characteristics}

The ultimate shear strength test was performed out according to (ASAE, 1999 b). The shear force was measured in double shear using a shear box (Fig. 1) consisting essentially of two fixed parallel hardened steel plates $15 \mathrm{~mm}$ apart, between which a third plate can slide freely in a close sliding fit. Shear force was applied to the specimens by mounting the shear box. The test was carried out between the standard Instron stainless steel polished platens of a model Instron Universal Testing Machine (Instron, USA) using a $1 \mathrm{kN}$ load cell. The shear stress was calculated as follows:

$$
\tau=\frac{F}{2 A}
$$

Where

$$
\begin{array}{rll}
\tau & : & \text { Shear stress, } \mathrm{MPa} . \\
\mathrm{F} & : & \text { Shearing force at failure, } \mathrm{N} . \\
\mathrm{A} & : & \text { Initial cross - sectional area, } \mathrm{mm}^{2} .
\end{array}
$$

The shearing energy was calculated by integrating the area under the shear force and displacement curve (Chen et al., 2004). The specific shearing energy was found as:

$$
E_{S C}=\frac{E_{S}}{A}
$$


Where

Esc : Specific shearing energy, $\mathrm{mJ} \mathrm{mm}^{-2}$.

Es : Shearing energy, $\mathrm{mJ}$.

A : Initial cross - sectional area, $\mathrm{mm}^{2}$.

The measured shearing properties of the garlic root and stem are presented in table (2).
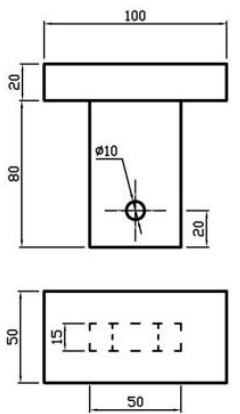

Loading plate
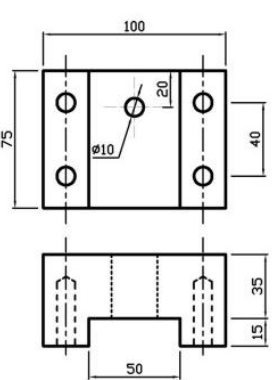

Supported plates

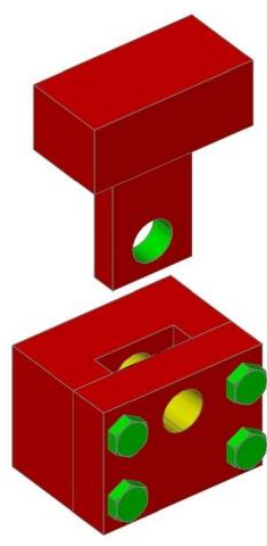

Fig. (1): The shear force measuring device. Table (2): Shearing characteristics of garlic root and stem.

\begin{tabular}{|c|c|c|c|c|}
\hline \multirow{2}{*}{ Property } & \multicolumn{4}{|c|}{ Value } \\
\hline & Min. & Max. & Mean & Stand. Dev. \\
\hline & \multicolumn{4}{|c|}{ Root } \\
\hline Shearing force, $\mathbf{N}$. & 1.10 & 3.75 & 1.98 & 0.63 \\
\hline Shearing stress, MPa. & 0.02 & 0.05 & 0.03 & 0.01 \\
\hline \multirow[t]{2}{*}{ Shearing energy, $\mathrm{mJ} \mathrm{mm}^{-2}$. } & 0.12 & 0.34 & 0.18 & 0.05 \\
\hline & \multicolumn{4}{|c|}{ Stem } \\
\hline Shearing force, $\mathbf{N}$. & 2.00 & 7.50 & 3.94 & 1.15 \\
\hline Shearing stress, MPa. & 0.13 & 0.32 & 0.22 & 0.07 \\
\hline 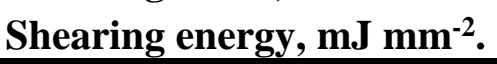 & 0.49 & 1.36 & 0.72 & 0.22 \\
\hline
\end{tabular}

\subsection{Developed machine}

The design following were considered in the of the machine ability to cut root and stem from the garlic bulb with a rate higher than the manual method, ease of operation, economy to make the machine affordable and within the capacity of the local farmers. The main components of the proposed machine 
are (Fig. 2): (1) cutting and cleaning units, (2) rotating shaft and bearings, (3) power transmission unit, and (4) main frame and supporting unit. The garlic plant is manually fed to the root cuter, root end down, through a protective guard shaped protective slot in the tabletop. The garlic bulb is stopped at the guard. Garlic bulbs with stems are horizontally fed, into the slot where they slide down through a guiding device and get cut by a cutting device. It is able to adjust the central positions of bulbs at an appointed point and is able to cut stems and roots of the individual bulbs to a predetermined extent, in spite of the variations of their size and shape. A discharge device below the rotating blade discharges the roots and debris through a duct to a collecting system.

\subsubsection{Frame and support}

The frame was manufactured locally from steel structures of angle-cross section ( $\mathrm{L} 40 \mathrm{~mm} \times 40 \mathrm{~mm} \times 4 \mathrm{~mm}$ ). The dimensions of the frame are $60 \mathrm{~cm}$ length, $50 \mathrm{~cm}$ width, and $70 \mathrm{~cm}$ height. The frame includes two parts first part for supporting the motor and second part for supporting the machine.

\section{.3.2 Power transmission unit}

Pulley size: The basic formula of designing a V-belt as the following, according to Khurmi and Gupta (2005):

$$
\mathrm{N}_{1} \mathrm{D}_{1}=\mathrm{N}_{2} \mathrm{D}_{2}
$$

Where

$\mathrm{N}_{1}, \mathrm{~N}_{2}$ : Speed of driving and driven pulley respectively, $\mathrm{rpm}$.

$\mathrm{D}_{1}, \mathrm{D}_{2} \quad$ : Diameter of driving and driven pulley respectively, $\mathrm{mm}$.

The machine will operate at three speeds: 1020 (8.5), 1440 (12.1) and 2448 (20.5) rpm $\left(\mathrm{m} \mathrm{s}^{-1}\right)$. So, Substituting the required speeds at the Knife $\left(\mathrm{N}_{1}\right.$ are 1020, 1440 and $2448 \mathrm{rpm}$, the rated speed of the electric motor $\mathrm{N}_{2}$ was 1440 $\mathrm{rpm}), \mathrm{D}_{1}$ and $\mathrm{D}_{2}$ where calculated as given in the table (3).

Table (3): Values of $D_{1}$ and $D_{2}$.

\begin{tabular}{cccccc}
\hline \multirow{2}{*}{$\begin{array}{c}\text { Knife velocity } \\
\left(\mathbf{m ~ s e c}^{-1}\right)\end{array}$} & \multicolumn{2}{c}{ Pulley of machine } & & \multicolumn{2}{c}{ Pulley of motor } \\
\cline { 2 - 3 } \cline { 5 - 6 } & $\mathbf{N}_{\mathbf{1}}(\mathbf{r p m})$ & $\left.\mathbf{D}_{\mathbf{1}} \mathbf{( m m}\right)$ & & $\mathbf{N}_{\mathbf{2}}(\mathbf{r p m})$ & $\mathbf{D}_{\mathbf{2}}(\mathbf{m m})$ \\
\hline 8.5 & 1020 & 120 & & 1440 & 85 \\
12.1 & 1440 & 85 & & 1440 & 85 \\
20.5 & 2448 & 50 & & 1440 & 85 \\
\hline
\end{tabular}




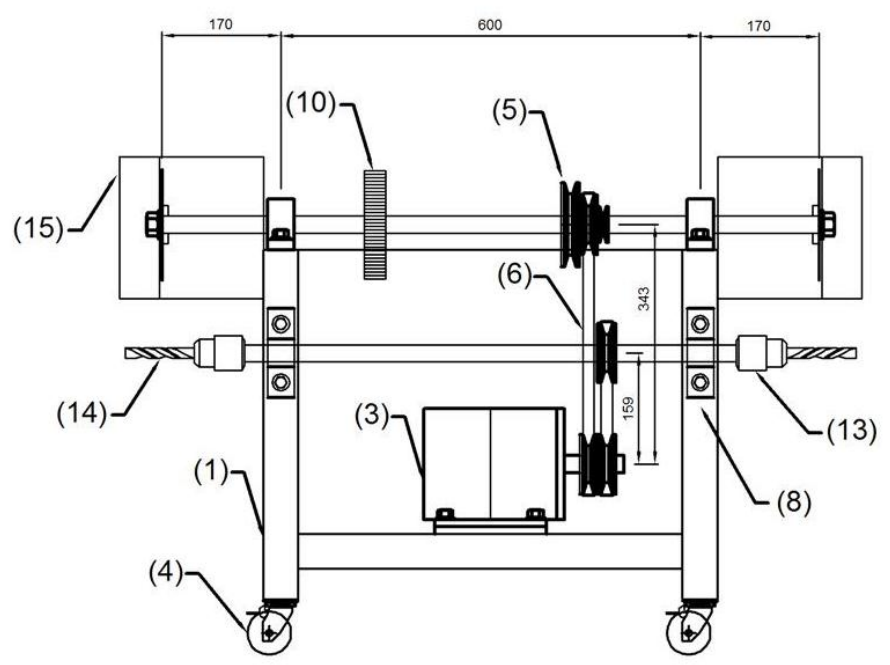

$\frac{a}{20}$

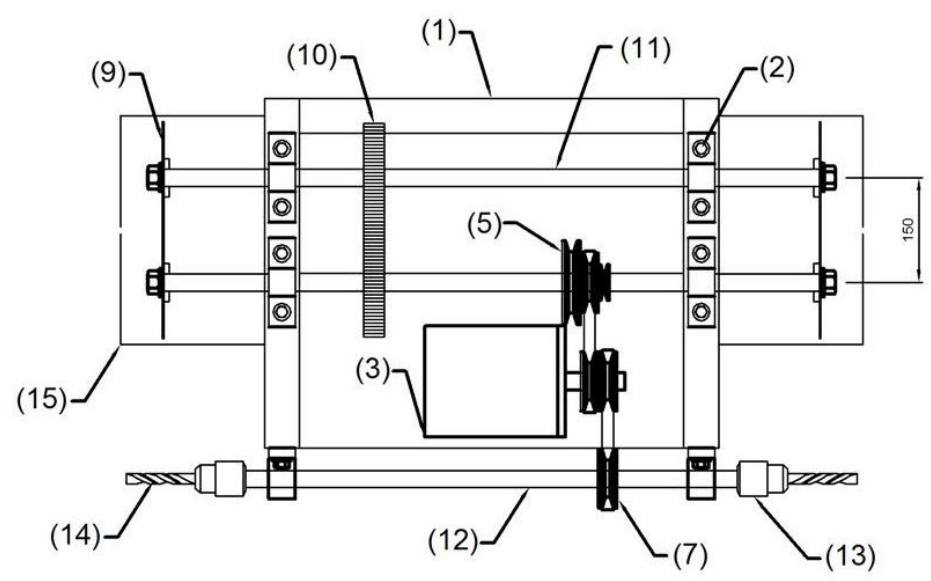

$\frac{5}{2}$

\begin{tabular}{|c|c|l|l|}
\hline 15 & 2 & Cover & St37 \\
\hline 14 & 2 & Twist Drill (Right + Left) & HSS \\
\hline 13 & 2 & Drill Chuck & St37 \\
\hline 12 & 10 & Side shaft & St50 \\
\hline 11 & 2 & Main shaft & St50 \\
\hline 10 & 2 & Spur gear 150 mm diameter & St37 \\
\hline 9 & 4 & Circular knife 160 mm Diamater & St 37 \\
\hline 8 & 6 & Bearing housing UCP205-100 & \\
\hline 7 & 1 & Single-pulleys blok & Al \\
\hline 6 & 1 & V-belt = 16mm & Rubber \\
\hline 5 & 2 & Malti-pulleys blok & Al \\
\hline 4 & 4 & Rotary caster single bearing wheel & \\
\hline 3 & 1 & Motor & \\
\hline 2 & 12 & Bolts and nut M10 & St37 \\
\hline 1 & 1 & Machine base & St37 \\
\hline Itemref & Quantity & Title/Name & Material \\
\hline $\begin{array}{c}\text { Designed by } \\
\text { Dr./Mohamed Ibrahim }\end{array}$ & Checked by & \\
\hline
\end{tabular}

Dims. in mm

Fig. (2): Diagrammatic sketch of the developed machine 
Length of belt $(\mathbf{L})$ : The $0.9 \mathrm{~m}$ length of the belt was calculated from the following equation:

$$
L=\frac{\pi}{2}\left(D_{1}+D_{2}\right)+2 x+\frac{\left(D_{1}-D_{2}\right)^{2}}{4 x}
$$

Where

X : Distance between centres of the two pulleys $(=40 \mathrm{~cm})$.

\subsubsection{Cutting and cleaning units}

The machine works on shear cutting principle. The cutting unit consists of two pairs of knife blade fixed on two shafts $(1,2)$. The cleaning unit consists of two twist drill and drill chuck; they fixed on shaft (3) as shown in Fig. (3).

\section{The power required for cutting the garlic stem}

In Fig. (4), A and B are the pair knives, $\mathrm{G}$ is the garlic stem, $\mathrm{W}$ is the weight of the garlic stem, Fc the normal force acting on the $\mathrm{G}$ and $\mathrm{Ft}$ is the tangential force acting the $\mathrm{G}$.

The power required to operate the machine is the first step to be consider in the design procedures. The power required to cut the garlic stem $(\mathrm{P}$, in $\mathrm{W})$ was estimated according to Shigley (2015) as follows:

$$
\mathrm{P}=\mathrm{n}_{\mathrm{r}} \mathrm{T} \omega
$$

Where

$\mathrm{P} \quad$ : Power required to cut the garlic stem, $\mathrm{W}$.

$\mathrm{n}_{\mathrm{r}} \quad$ : Number of the rotating knives $\left(\mathrm{n}_{\mathrm{r}}=4\right)$.

$\omega$ : Angular velocity of the roller, $\mathrm{rad} / \mathrm{second},\left(\omega=2 \pi \mathrm{N}_{\mathrm{s}} / 60\right)$.

$\mathrm{N}_{\mathrm{S}}:$ Roller speed, $\mathrm{rpm}\left(\mathrm{N}_{\mathrm{S}}=2448 \mathrm{rpm}\right)$.

$\mathrm{T}:$ : Torque, $\mathrm{N}-\mathrm{m}=\mathrm{r} \mathrm{F}_{\mathrm{t}}$.

$\mathrm{r} \quad$ : Radius of the rotating knife, $\mathrm{m}(\mathrm{r}=0.80 \mathrm{~m})$.

$\mathrm{F}_{\mathrm{t}} \quad$ : Total friction force between the knife surface and the garlic stem $=$ the tangential force. 

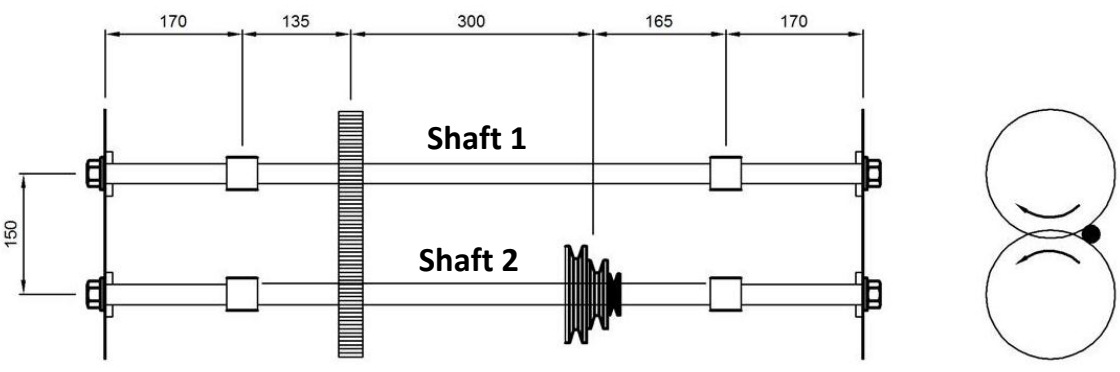

(a) Root and stem cutting unit

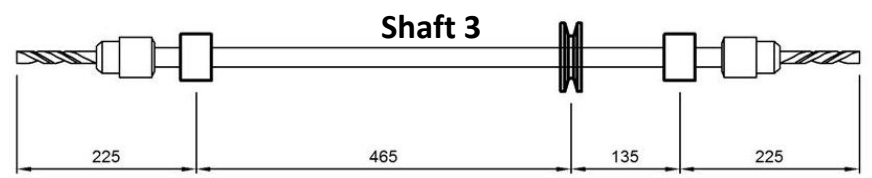

(b) Root cleaning unit

Fig. (3): Cutting and cleaning units.

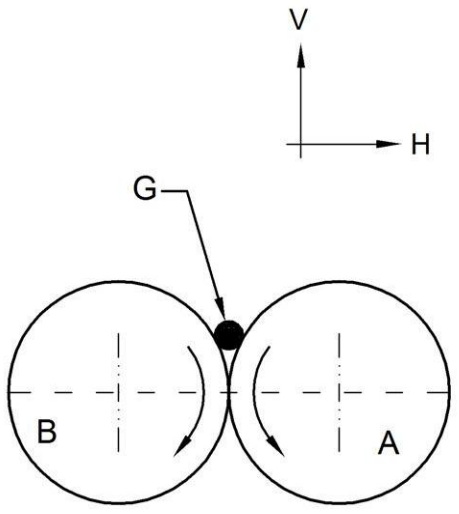

(a)

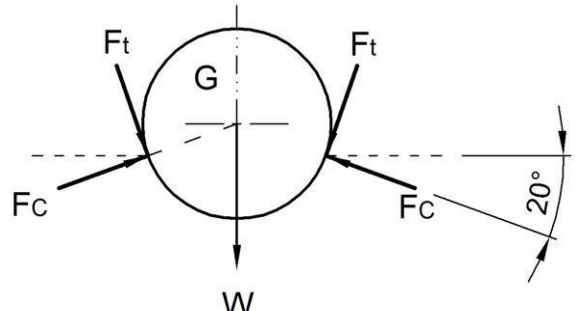

(b)

Fig. (4): Diagrammatic sketch for the forces acting on a garlic stem during the cutting process: (a) Pair knives, (b) a garlic stem.

For one garlic stem, the normal force $\left(2 \times \mathrm{F}_{\mathrm{N}}\right)$ that is required to cut one garlic stem (shear force for cutting garlic stem), it was measured to be $7.5 \mathrm{~N}$ (Table 2$),\left(\mathrm{F}_{\mathrm{N}}=3.75 \mathrm{~N}\right)$ and the corresponding tangential force $(\mathrm{Ft})$ was estimated based on a friction coefficient $(\mu=0.7)$ between the steel and the garlic stem (Table 1); the value of $\mathrm{Ft}=\mu \mathrm{F}_{\mathrm{N}}$ is equals to $2.625 \mathrm{~N}$. Accordingly, the number of the garlic stem that will be cut simultaneously is 2. The value of $\mathrm{T}$ (in Eq., 5) is equal to $0.21 \mathrm{~N}-\mathrm{m}$ and the power required (Eq. 
2) is equal to 215.23 watt to operate the cutting shafts at $2448 \mathrm{rpm}$. The chosen power engine is $0.5 \mathrm{HP}=375 \mathrm{~W}$.

Design of the rotating shaft (No. 2): In order to transfer the power from the shaft, the various members (such as pulleys) are mounted on it. The design of shaft is based on combined shock and fatigue, Bending and torsional moment (Fig. 7).

Hence, the diameter of the shaft was calculated as follows (Eric, 1976):

$$
d^{3}=\frac{16}{\pi S_{s}} \sqrt{\left[K_{b} M_{b}\right]^{2}+\left[K_{t} M_{t}\right]^{2}}
$$

Where

d : Diameter of shaft, $\mathrm{m}$.

$\mathrm{M}_{\mathrm{b}}$ : Resultant bending moment, N-m.

$\mathrm{M}_{\mathrm{t}}$ : Torsional moment, N-m.

$\mathrm{K}_{\mathrm{b}}$ : Combined shock and fatigue factor applied to bending moment.

$\mathrm{K}_{\mathrm{t}}$ : Combined shock and fatigue factor applied to torsional moment.

Ss : Allowable shear stress of the shaft material, $\mathrm{MN}-\mathrm{m}^{-2}$.

The values of $\mathrm{K}_{\mathrm{b}}$ and $\mathrm{K}_{\mathrm{t}}$ were taken as 1.5 and 1.0 respectively for the gradually applied load on the rotating shaft and the allowable shear stress of the shaft ( $\mathrm{Ss}$ ) as $40 \mathrm{MN}-\mathrm{m}^{-2}$ based on ASME code.

$\mathrm{M}_{\mathrm{b}}$ was calculated by analyzing moments due to both horizontal and vertical loading in bending moment diagrams of the shaft.

$\mathrm{M}_{\mathrm{t}}$ was calculated by the following equation:

$$
M_{t}=\frac{P \times 60}{2 \pi N}
$$

Using $\mathrm{P}=375 \mathrm{~W}$ and $\mathrm{N}=1020 \mathrm{rpm}$, the maximum $\mathrm{M}_{\mathrm{t}}$ was calculated as $\mathbf{3 . 5 1}$ $\mathrm{N}-\mathrm{m}$.

\section{Determination of the Maximum Bending Moment:}

The position of the electric motor in relation to the main shaft is such that $T_{1}$ and $\mathrm{T}_{2}$ act vertically downward.

\section{For the pulley:}

Weight of pulley $(\mathrm{Wp})=\mathrm{Vp} \times \rho_{\mathrm{p}} \times \mathrm{g}$

Where

Vp : Volume of the pulley, $\mathrm{m}^{3}(120 \mathrm{~mm}$ - diameter and $40 \mathrm{~mm}-$ thick)

$\rho_{p}:$ Density of the pulley material (for aluminium $=2700 \mathrm{~kg} \mathrm{~m}^{-3}$ ). So, $\mathrm{Wp}=16.3 \mathrm{~N}$. 
According to ASTM Standards, the V-belt is $16 \mathrm{~mm}$ that can transmit 2-15 $\mathrm{kW}$.

Belt Force: The power transmitted by a belt drive is a function of the belt tensions and belt speed. The belt tensioning forces on the pulley was calculated according to the following equations (Khurmi and Gupta, 2005).

$$
\begin{aligned}
& 2.3 \log \mathrm{T}_{1} / \mathrm{T}_{2}=\mu \theta \operatorname{cosec} \beta \\
& \mathrm{Mt}=\left(\mathrm{T}_{1}-\mathrm{T}_{2}\right) \mathrm{R}_{1}
\end{aligned}
$$

Where

$\mathrm{T}_{1}$ : Belt tension in tight side, $\mathrm{N}$.

$\mathrm{T}_{2}$ : Belt tension in loose side, $\mathrm{N}$.

$\mu \quad$ : Coefficient of friction between belt and pulley $(\mu=0.25)$.

$\theta \quad: \quad$ Belt wrap angle, radian $=(180-2 \alpha) \pi / 180$.

$\alpha \quad: \quad \sin \alpha=\frac{D_{1}-D_{2}}{2 x}$.

$\mathrm{x} \quad$ : Distance between centres of the two pulleys $(=37 \mathrm{~cm})$.

$2 \beta$ : Groove angle of the pulley $\left(32^{\circ}\right)$.

Mt : Torsional moment (N-m).

$\mathrm{R}_{1} \quad$ : Radius of the machine pulley (m).

Torque transmitted by the pulley $(\mathrm{Mt})=\mathbf{3 . 5 1} \mathrm{N}-\mathrm{m}$. From the previous equations, $T_{1}$ and $T_{2}$ were calculated and are given in table (4):

Table (4): Values of $T_{1}$ and $T_{2}$.

\begin{tabular}{lllclccc}
\hline $\begin{array}{c}\mathbf{D}_{1} \\
(\mathbf{m m})\end{array}$ & $\begin{array}{c}\mathbf{D}_{\mathbf{2}} \\
(\mathbf{m m})\end{array}$ & $\begin{array}{c}\mathbf{A} \\
(\mathbf{d e g r e e})\end{array}$ & $\begin{array}{c}\boldsymbol{\theta} \\
(\mathbf{r a d} .)\end{array}$ & $\mathbf{T}_{\mathbf{1}} / \mathbf{T}_{\mathbf{2}}$ & $\begin{array}{r}\mathbf{T}_{\mathbf{1}} \\
(\mathbf{N})\end{array}$ & $\begin{array}{c}\mathbf{T}_{\mathbf{2}} \\
(\mathbf{N})\end{array}$ & $\begin{array}{c}\mathbf{T}_{\mathbf{1}}+\mathbf{T}_{\mathbf{2}} \\
(\mathbf{N})\end{array}$ \\
\hline 120 & 85 & 0.047 & 2.7 & 15.86 & 62.44 & 3.94 & 66.37 \\
85 & 85 & 0 & 0 & 17.3 & 87.65 & 5.07 & 92.72 \\
50 & 85 & -0.047 & 2.7 & 15.86 & 149.85 & 9.45 & 159.30 \\
\hline
\end{tabular}

The maximum value of $\left(T_{1}+T_{2}\right)$ with $T_{1}=\mathbf{1 4 9 . 8 5}$ and $T_{2}=9.45 \mathrm{~N}$ was taken in the calculations. So, Total load acting on pulley $=T_{1}+T_{2}+W p=297.15 ~ N$. For the knife

$$
\text { Weight of knife }\left(\mathrm{W}_{\mathrm{C}}\right)=\rho \times \mathrm{Vc} \times \mathrm{g}
$$

Where

$\rho \quad: \quad$ Density of the Material (for steel, $7800 \mathrm{~kg} \mathrm{~m}^{-3}$ ).

$\mathrm{V}_{\mathrm{C}}$ : Volume of the knife.

g : Acceleration due to gravity. 
So, the weight of knife $\left(\mathrm{W}_{\mathrm{C}}\right)=\mathbf{3 . 1} \mathbf{N}$. Normal force extorted by garlic stem on the one knife $\left(\mathrm{F}_{\mathrm{N}}\right)=\mathbf{3 . 7 5} \mathbf{N}$, this load acts at $20^{\circ}$ to the horizontal as shown in Fig. (5)

Resolving the load $\mathrm{F}_{\mathrm{N}}$ into vertical and horizontal components (Fig. 5), the vertical component $=\mathrm{F}_{\mathrm{N}} \sin 20^{\circ}=3.75 \times \sin 20^{\circ} \quad=\mathbf{1 . 2 8} \mathrm{N}$ The horizontal component of $=\mathrm{F}_{\mathrm{N}} \cos 20^{\circ}=3.75 \times \operatorname{Cos} 20^{\circ}=\mathbf{3 . 5 2} \mathrm{N}$

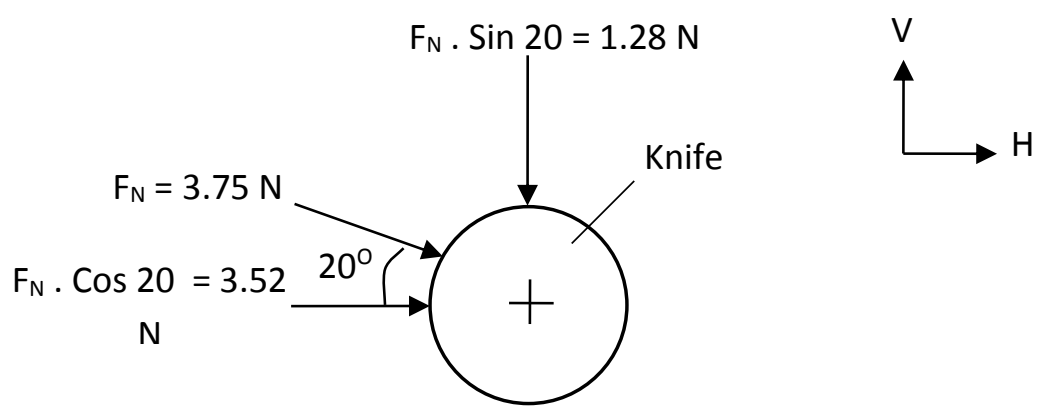

Fig. (5): The normal force due to the cutting.

Vertical loading $\left(\mathbf{F}_{\mathbf{T V}}\right)$ on the shaft $=\mathrm{F}_{\mathrm{N}} \operatorname{Sin} 20+\mathrm{W}_{\mathrm{C}}=1.28+3.1=\mathbf{4 . 3 8} \mathbf{N}$. Horizontal loading $\left(\mathbf{F}_{\mathbf{T H}}\right)$ on the shaft $=\mathbf{3 . 5 2} \mathbf{N}$.

For the gear: The forces act on the gear is shown in Fig. (6)

$$
\text { Weight of gear }\left(\mathrm{W}_{\mathrm{G}}\right)=\rho \times \mathrm{V}_{\mathrm{G}} \times \mathrm{g}
$$

Where

$\rho \quad: \quad$ Density of the Material (for steel, $7800 \mathrm{~kg} \mathrm{~m}^{-3}$ ).

$\mathrm{V}_{\mathrm{G}}$ : Volume of the gear.

$\mathrm{g}:$ : Acceleration due to gravity.

So, the weight of gear $\left(\mathbf{W}_{\mathbf{G}}\right)=43.29 \mathrm{~N}$.

$$
\begin{gathered}
F_{t}=\frac{P}{r \times \omega} \\
\mathrm{F}_{\mathrm{r}}=\mathrm{F}_{\mathrm{t}} \times \tan \phi
\end{gathered}
$$

Where

$\mathrm{F}_{\mathrm{t}} \quad$ : The tangential force, $\mathrm{N}$.

$\mathrm{P}$ : Power required to cut the garlic stem, W.

$\mathrm{r} \quad$ : Radius of the pitch circle $(\mathrm{r}=77.5 \mathrm{~mm})$.

$\omega$ : Angular velocity of the gear, in $\mathrm{rad} /$ second, $\left(\omega=2 \pi \mathrm{N}_{\mathrm{s}} / 60\right)$.

$\mathrm{N}_{\mathrm{S}}:$ Gear speed (in rpm) $=1020 \mathrm{rpm}$.

$\mathrm{F}_{\mathrm{r}} \quad$ : The radial force, $\mathrm{N}$.

$\phi \quad$ : Pressure angle of the tooth $\left(\phi=20^{\circ}\right)$.

So, $F_{t}=0.76 \mathrm{~N}$ and $F_{r}=0.28 \mathrm{~N}$. 
The horizontal force acting on the gear $=\mathbf{0} .28 \mathrm{~N}$.

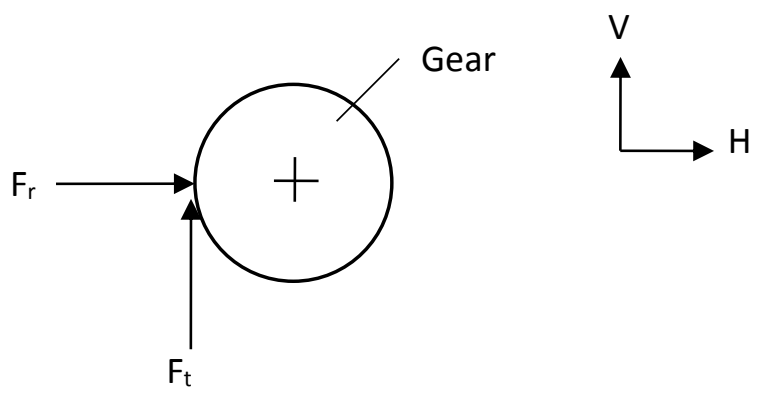

Fig. (6): The forces act on the gear.

Accordingly, the shaft is subjected to vertical loads of the values presented in table (5) and Fig. (7).

Table (5): Vertical and horizontal loads on the shaft (N).

\begin{tabular}{lcccc}
\hline Type of load & At $($ A) & At $(B)$ & At $(C)$ & At $(D)$ \\
\hline Vertical & 4.38 & 43.29 & 297.15 & 4.38 \\
Horizontal & 3.52 & 0.28 & & 3.52 \\
\hline
\end{tabular}

The bending moment diagram for vertical and horizontal loading are shown in Fig. (7).

From the shear force diagram of Fig. (7), it is obvious that $C$ is the point of maximum bending moment. Maximum bending moment $\left(\mathrm{M}_{\mathrm{b}}\right)$ was found to be $\mathbf{M}_{\mathbf{b}}=\mathbf{3 6 . 4 1} \mathrm{N}-\mathrm{m}$. The maximum torque was found to be $\mathbf{M}_{\mathbf{t}}=\mathbf{3 . 5 1} \mathrm{N}-\mathrm{m}$.

By applying in the equation (6), shaft diameter (d) should be equal or more than $19.13 \mathrm{~mm}=20 \mathrm{~mm}$.

\subsubsection{Bearing selection}

The selection of a rolling bearing is made from a manufacturer's catalogue. By using FAG rolling bearing catalogue for the machine ball bearing was selected.

\subsubsection{Electric motor}

A single phase electric motor with a rated speed of a $1440 \mathrm{rpm}$ and power of $0.5 \mathrm{hp}$ was used.

\subsection{Performance evaluation}

According to literature data (ASAE, 1999c; Srivastava et al., 2006; CIGR, 1999), evaluation parameters of the developed machine were machine capacity, bulb damaged, consumed energy and cost. The development machine was evaluated at two different levels of moisture content of garlic and three levels of knife speed (Table 6). 


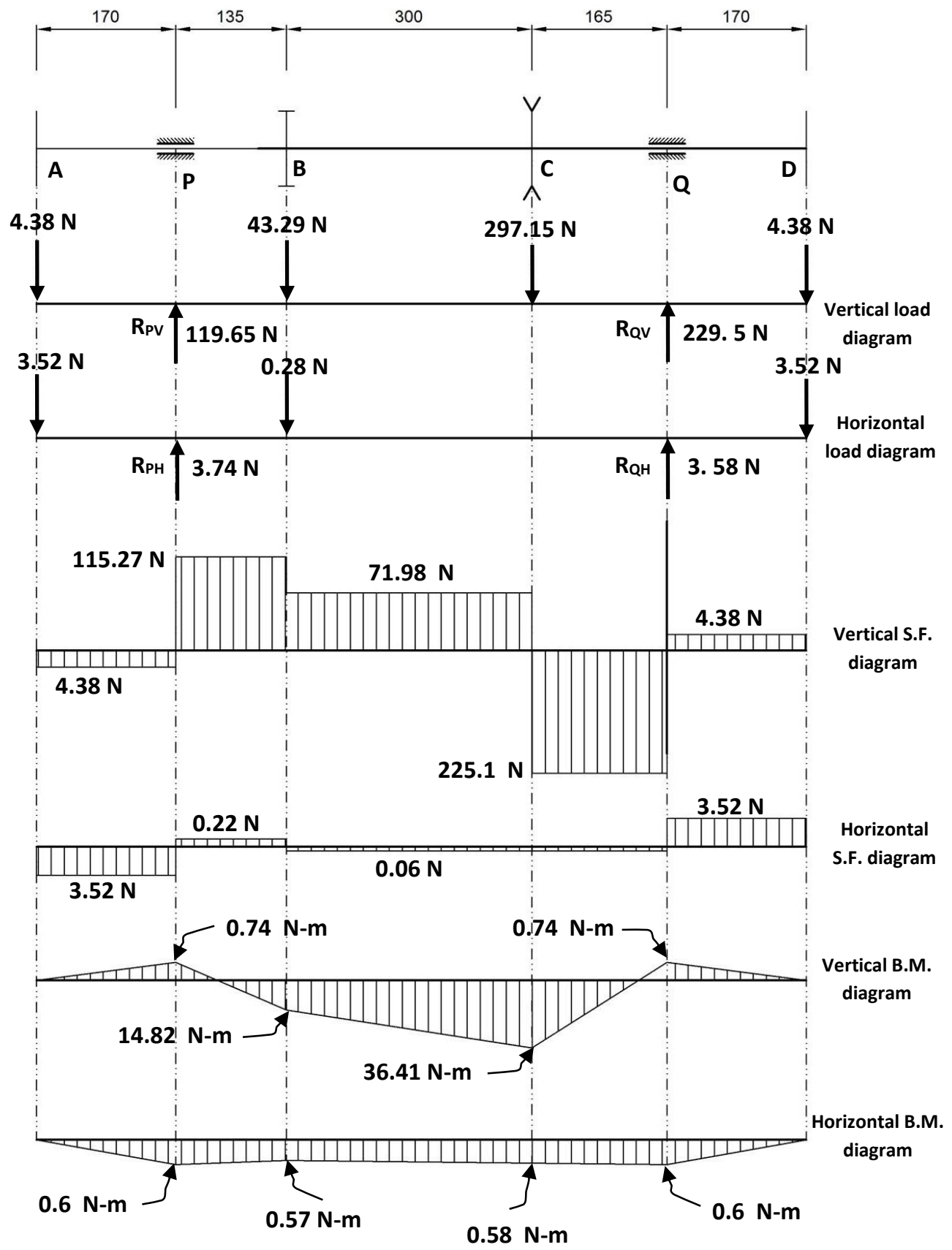

Fig. (7): The shearing and bending moment diagrams of the shaft. 
Table (6): Experimental plan for evaluating the machine.

\begin{tabular}{ll}
\hline \multicolumn{1}{c}{ Variables } & Levels \\
\hline Moisture content, $\mathrm{M}_{\mathrm{C}}(\% \mathrm{w} . \mathrm{b})$ & $61.5,70.3$ \\
Knife speed, $\mathrm{K}_{\mathrm{S}}, \mathrm{m} \mathrm{s}^{-1}(\mathrm{rpm})$ & $1020(8.5), 1440(12.1)$ and 2448 \\
& $(20.5)$ \\
\hline
\end{tabular}

\subsubsection{Machine capacity $\left(\mathbf{P}_{\mathrm{m}}\right)$}

The machine capacity was calculated as follows:

$$
P_{m}=\frac{N_{P}}{T}
$$

Where

$\mathrm{P}_{\mathrm{m}} \quad$ : The machine capacity, piece $\mathrm{h}^{-1}$.

$\mathrm{N}_{\mathrm{p}} \quad$ : Number of cutting, piece.

$\mathrm{T}$ : Cutting time, hour.

\subsubsection{Bulb damage (BD)}

Bulb damage percentage (BD) was calculated by the following equation:

$$
\mathrm{BD}(\%)=\frac{\text { Number of damaged bulb }}{\text { Total weight of bulb }} \times 100
$$

\subsubsection{Required power (RP) and consumed energy (CE)}

The required electric power under machine working load (RP) was calculated as Chancellor (1981) by the following equation:

$$
\mathrm{RP}=\mathrm{V} \times \mathrm{I} \times \cos \theta
$$

Where

$$
\begin{array}{lll}
\text { RP } & : & \text { The required power for separating bulb, W. } \\
\text { V } & : & \text { Potential difference, Volt (single phase = } 220 \text { volt). } \\
\text { I } & : & \text { Line current intensity, Amperes. } \\
\cos \theta & : & \text { Power factor (0.64). }
\end{array}
$$

A digital clamp meter and Voltmeter were used for measuring current intensity and voltage respectively.

The consumed energy (CE) is specific power per unit capacity; it was calculated by using the following equation:

$$
\text { Consumed energy }=\left(\mathrm{RP} / \mathrm{P}_{\mathrm{m}}\right), \quad \mathrm{W} \text { h piece }{ }^{-1}
$$




\subsubsection{Costs}

Machine cost was determined using the fixed costs and variable costs according to Srivastava et al. (2006). The estimated cost of the cutting machine was about 5000 L.E. The operational cost was determined using the following equation:

$$
\text { Operating costs }=\frac{\text { Machine cost }\left(\mathrm{L} \cdot \mathrm{E} \mathrm{h}^{-1}\right)}{\text { Machine capacity }\left(\text { piece }^{-1}\right)}
$$

\section{RESULTS AND DISCUSSIONS}

\subsection{Machine capacity $\left(\mathbf{P}_{\mathrm{m}}\right)$}

The machine capacity ranged from 522 to 728 Piece $^{-1}$ with knife speed of 8.5 to $20.5 \mathrm{~m} \mathrm{~s}^{-1}$ and moisture content of 61.5 to $70.3 \%$. The machine capacity was influenced by the knife speed and moisture content. The machine capacity was the least at the lowest knife speed of $8.5 \mathrm{~m} \mathrm{~s}^{-1}$ and increased with increasing speed. This due to with increasing the knife speed the root and stem cut easily. The machine capacity decreased with increasing moisture content, this due to increase the cutting strength of root and stem, as shown in figure (8).

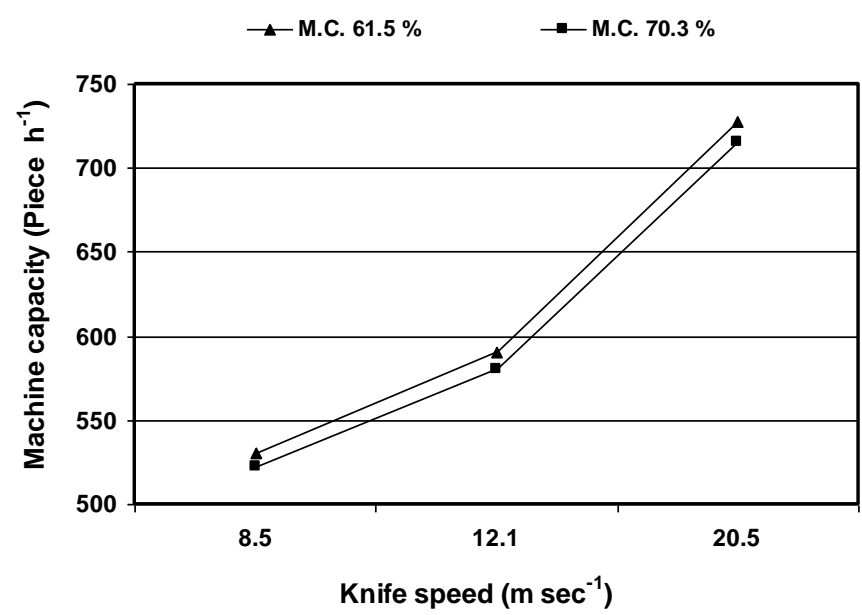

Fig. (8): The effects of knife speed and moisture content on machine capacity.

\subsection{Bulb damage (BD)}

The bulb damage percentage ranged from $3 \%$ to $4.8 \%$ with knife speed of 8.5 to $20.5 \mathrm{~m} \mathrm{~s}^{-1}$ and moisture content of 61.5 to $70.3 \%$. The bulb damage was influenced by the knife speed and moisture content. The bulb damage 
was the least at the lowest knife speed of $8.5 \mathrm{~m} \mathrm{~s}^{-1}$ and increased with increasing speed. The bulb damage increased with reduction in moisture content, as shown in figure (9).

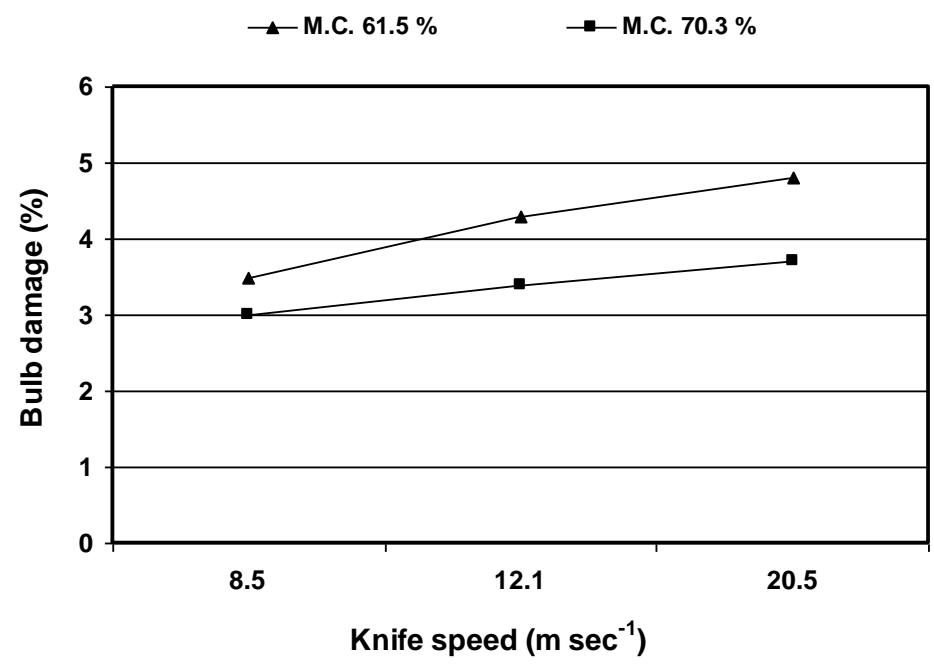

Fig. (9): The effects of knife speed and moisture content on bulb damage

\subsection{Consumed energy (CE)}

percentage.

The consumed energy ranged from 0.27 to $0.48 \mathrm{~W} \mathrm{~h} \mathrm{piece}^{-1}$ for knife speed of 8.5 to $20.5 \mathrm{~m} \mathrm{~s}^{-1}$ and moisture content of 61.5 to $70.3 \%$. The consumed energy was influenced by the knife speed and moisture content. The consumed energy was the least at the lowest knife speed of $8.5 \mathrm{~m} \mathrm{~s}^{-1}$ and increased with increasing in speed, this due increasing in required power with increase the speed. The consumed energy was almost same at the moisture contents of $61.5 \%$ to $70.3 \%$, as shown in figure (10).

The most suitable conditions for machine that take the best cutting condition: were observed at combinations of knife speed $=8.5 \rightarrow 20.5 \mathrm{~m} \mathrm{~s}^{-1}$ and moisture content value of $61.5 \%$.

\subsection{Techno-economic feasibility}

The cost of cutting the garlic root and stem was 6.3 L.E for 100 pieces $^{-1}$ which were much cheaper than the manual method (8.9 L.E for 100 pieces $^{-1}$ ) according to 2018 local conditions. Using the developed machine increased the capacity to about 1.5 times and reduced the separation cost to about 29.2 $\%$ comparing with manual method, as shown in figure (11). 


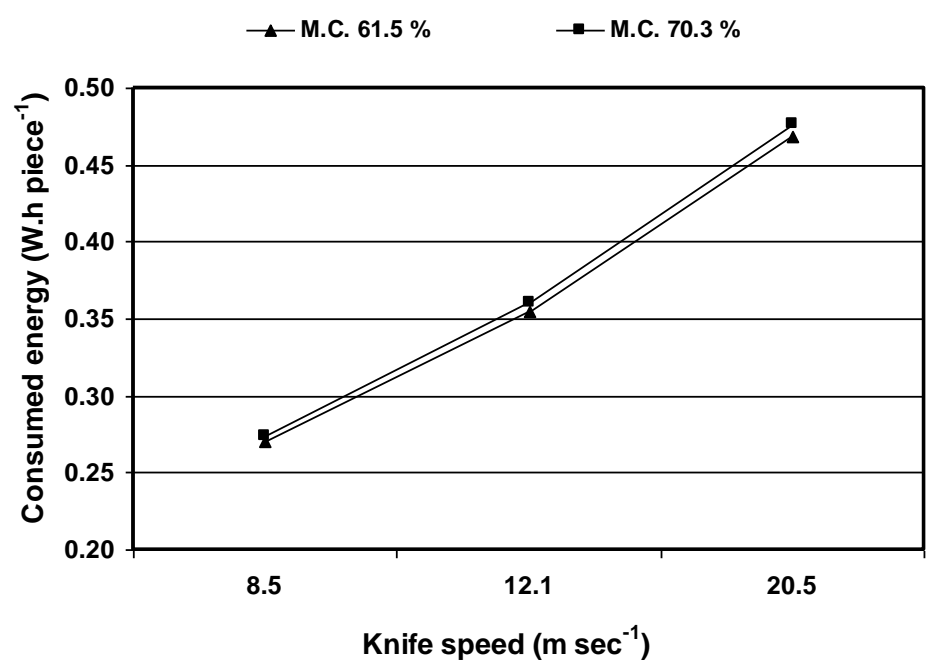

Fig. (10): The effects of knife speed and moisture content on consumed energy.

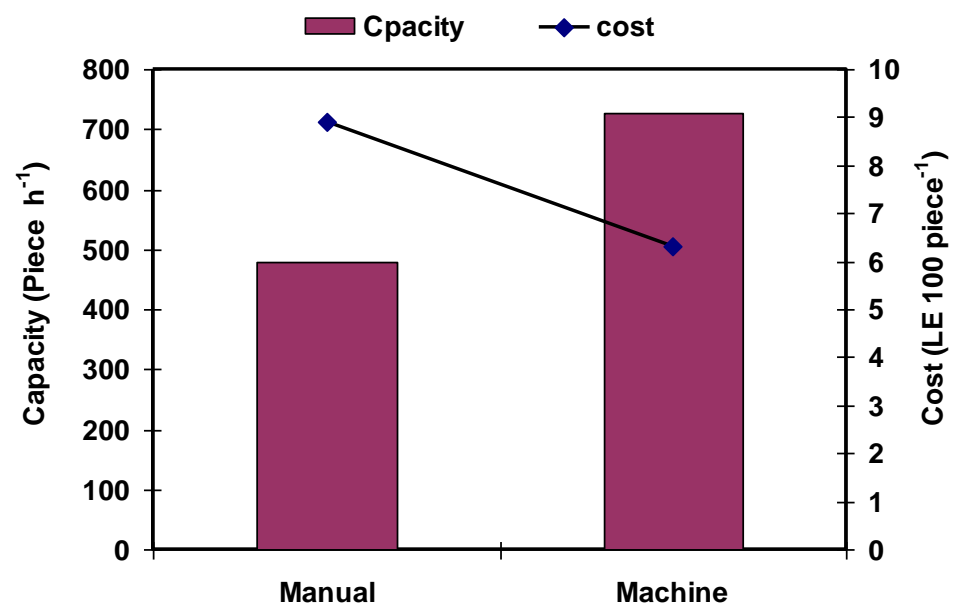

Fig. (11): Capacity and cost of the garlic cutting with manual and mechanical methods.

\section{CONCLUSION}

The obtained results can be summarized as follows:

1. Machine capacity increased with the increase of knife speed, and decrease in moisture content.

2. Bulb damage increased with the increase in knife speed, but decreased with increase in moisture content. 
3. Consumed energy increased with the increase in moisture content, and knife speed.

4. It is recommended to use the following operating variables at combinations of knife speed $=8.5 \rightarrow 20.5 \mathrm{~m} \mathrm{~s}^{-1}$ and moisture content value of $61.5 \%$

5. Using the developed machine increased the capacity to about 1.5 times and reduced the separation cost to about $29.2 \%$ comparing with manual method.

\section{REFERENCES}

ASAE Standards. 1999a. Moisture measurement - unground grain and seeds. ASAE S352.2 DEC97. St. Joseph, MI: ASAE.

ASAE Standards. 1999b. Shear and three-point bending test of animal bone. ASAE S459 MAR98. St. Joseph, MI: ASABE.

ASAE Standards. 1999c. S343.3: Terminology for combines and grain harvesting. St. Joseph, Mich.: ASAE.

Chancellor, W. J. 1981. Substituting information for energy in agricultural. Trans. ASAE Paper No. 0001- 2351.

Chen, Y., J. L. Gratton, and J. Liu. 2004. Power requirements of hemp cutting and conditioning. Biosys. Eng., 87(4), 417-424.

CIGR. 1999. Handbook of agricultural engineering. Volume III. Plant Production Engineering. The International Commission of Agricultural Engineering. Published by the ASAE.

Eric, O. 1976. 20th ed. Machinery's Hand Book New York, Industrial Press .

FAOSTAT. 2016. FAO Statistical Yearbook. Agricultural production.

Gil, M. I. and A. Allende. 2012. Minimal processing. Decontamination of fresh and minimally processed produce, $\mathrm{p} 105$.

Ibrahim, M. M. 2013. Development of a garlic bulb separator: 1. Separating unit. Misr J. Ag. Eng., 30(1): 1- 27.

Khurmi, R. S. and J. K. Gupta. 2005. Theory of Machines. New Delhi:Eurasia Publishing house. 
Koidis, A., A. Rawson, M. Tuohy and N. Brunton. 2012. Influence of unit operations on the levels of polyacetylenes in minimally processed carrots and parsnips: an industrial trial. Food Chem 132:1406-1412.

Mishra, B. B., S. Gautam and A. Sharma. 2012. Browning of fresh-cut eggplant: impact of cutting and storage. Postharvest Biol Technol $67: 44-51$.

Ngamchuachit, P., H. K. Sivertsen, E. J. Mitcham and D. M. Barrett. 2014. Effectiveness of calcium chloride and calcium lactate on maintenance of textural and sensory qualities of fresh-cut mangos. $\mathbf{J}$ Food Sci 79:C786-C794.

Qi, H. P., W. Z. Hu, A. L. Jiang and M. X. Tian. 2011. Effect of mechanical damage on the potato's nutrients with various distance. Adv Mater Res. 236:2973-2979.

Russo, V. C., É. R. Daiuto and R. L. Vieites. 2012. Fresh cut yellow melon (CAC) submitted to different type cuts and concentrations of calcium chloride stored under modified passive atmosphere. Semina: Ciências Agrárias (Londrina) 33:227-236.

Shigley, J. E. 2015. Mechanical Engineering Design. S.I (Metric Ed.). New York: Tata, Mcgraw-Hill Publishing Company Limited.

Srivastava, A. K., C. E. Goering, R. P. Rohrbach and D. R. Buckmaster. 2006. Engineering principles of agricultural machines. St. Joseph, Mich.: ASAE.

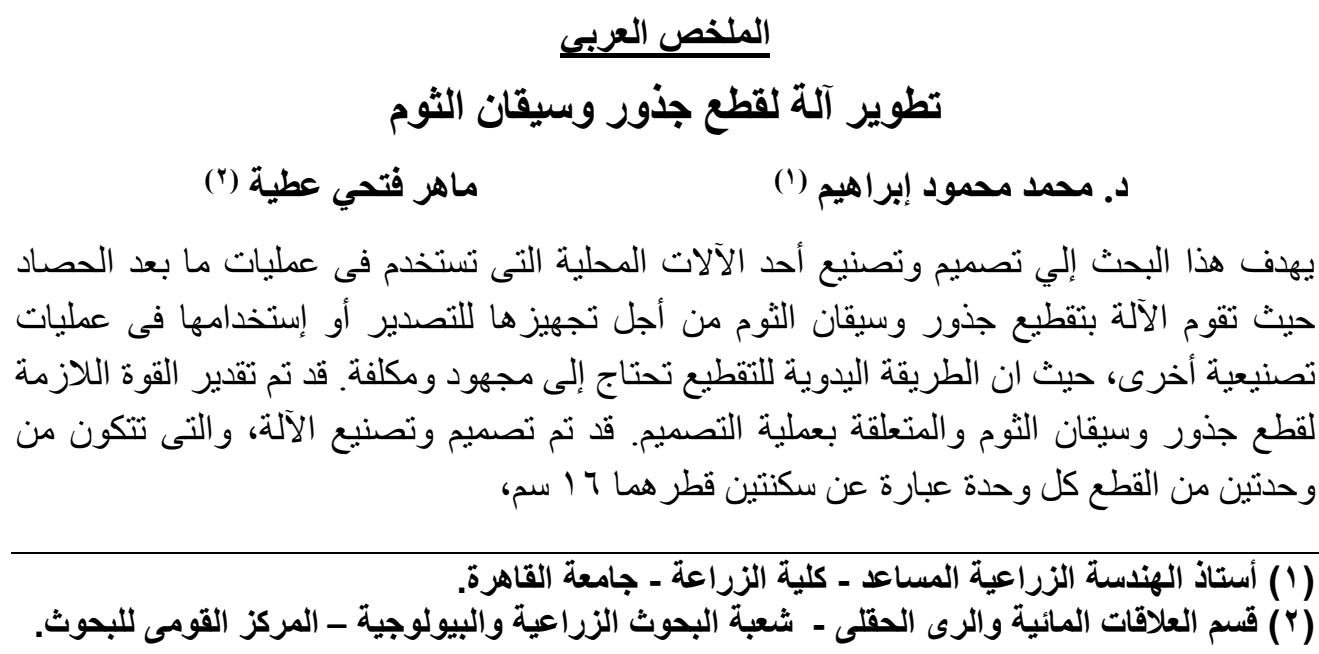


بالإضافة إلى وحدة لعملية التنظيف للجذور الصغيرة، ومجموعة لنقل الحركة بالإضافة إلى محرك

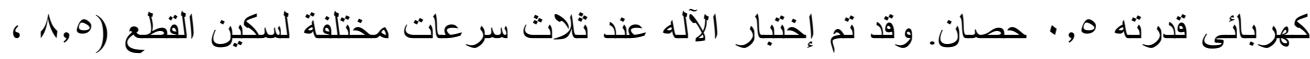

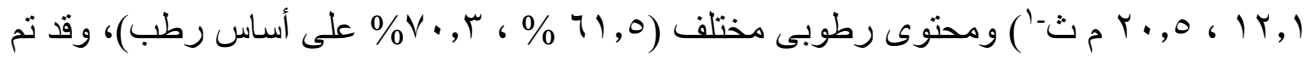

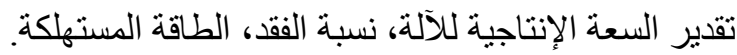

$$
\text { وق بينت الاراسة ما يلي: }
$$

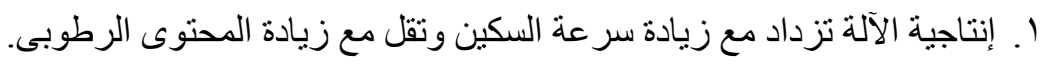

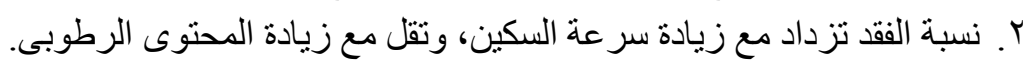

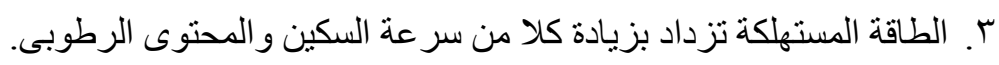

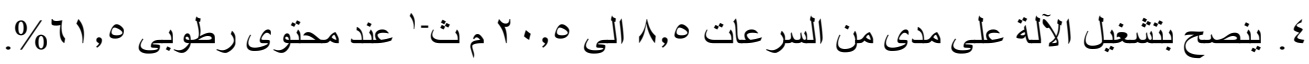

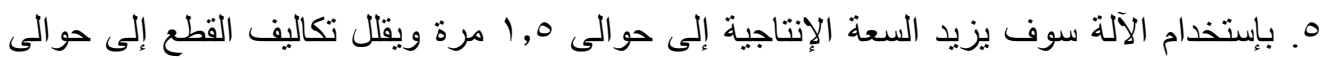

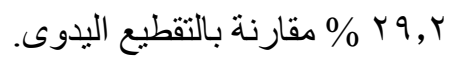

